\title{
Effect of Pruning Intensity on Growth Characteristics of Some Timber Trees Grown under Treated Wastewater Irrigation
}

\author{
${ }^{1}$ Hammad H.H., M.I. Bahnasy' ${ }^{1}$ and H. El-kateb² \\ ${ }^{I}$ Forestry and Timber Trees Dept., Hort. Res. Inst., A.R.C., Giza, Egypt. \\ ${ }^{2}$ Institute of Silviculture, Technische Universitat Munchen, Germany
}

Received: 23 March 2020 / Accepted 21 May 2020 / Publication date: 20 June 2020

\begin{abstract}
This study was carried out at Sarabium forestry Plantation located in North eastern Egypt which was allocated for wastewater disposal. The study aimed to determine the optimal pruning intensities on growth characteristics of four tree species namely; Khaya senegalensis, Swietenia mahagoni, Gmelina arborea and Tectona grandis. The results indicated that, all growth characteristics (total height, root collar diameter, stem diameter at breast height and total biomass) were significantly increased in $G$. arborea followed by $S$. mahagoni, K. senegalensis and T. grandis. Pruning intensity of 30 and $50 \%$ of tree height significantly increased all growth characteristics as compared to non- pruned trees. Also pruning intensity of $30 \%$ of tree height significantly increased all growth characteristics in $K$. senegalensis and $T$. grandis. On the other hand, pruning intensity of $50 \%$ of tree height significantly increased all growth characteristics were studied in S. mahagoni and G. arborea. In addition, pruning intensity of $50 \%$ increased total volume of $G$. arborea followed by pruning intensity at $30 \%$. N, P and $\mathrm{K}$ in the tree species leaves were increased under $50 \%$ pruning intensity of G. arborea and $S$. mahagoni, while N, P and K values were increased under $30 \%$ pruning intensity in $K$. senegalensis and $T$. grandis.
\end{abstract}

Keywords: timber tree species, wastewater, pruning intensity, growth measurements, total biomass.

\section{Introduction}

Khaya senegalensis (Desr.), belongs to Meliaceae Family, its wood is hardwood with excellent commercial value and physical and mechanical properties. It is one of the most economically important trees and used for high-class furniture, joinery, building and construction purposes. It has also high traditional medicinal values and used as an ornamental tree for gardens and avenues (Nikiema and Pasternak, 2008).

Swietenia mahagoni (L.) Jacq., Family Meliaceae; is a long tree, up to $30 \mathrm{~m}$ height and up to 1 $\mathrm{m}$ in diameter. The heart wood is very resistant to decay and insect infestation, which makes it a favorite for other mahogany types in world markets. It produces the finest quality wood, cabinetwork, joinery, boats and pattern work (Orwa et al., 2009).

Gmelina arborea Roxb, Family Lamiaceae, the wood produces good-quality pulp, particle board, the manufacture of furniture, matches and timber for light construction (Roshetko et al., 2003).

Teak (Tectona grandis L.) Family Lamiaceae, is recognized for its physical and aesthetic qualities as one of the most important and valuable hardwoods in the world.

Teak is used for ship building and yacht furnishing, heavy duty construction and railways, highclass furniture, decorative building components, veneers, flooring, and utility poles for transmission lines. the high market value of teak to its excellent durability in tropical climates and its resistance to termite attack and fungi, and praised teak as it is easily worked, does not warp or split, takes a beautiful polish, and can be floated at harvest in contrast to many other heavy hardwoods of comparable quality . For many tropical countries teak represents the best opportunity to produce quality timber and is thus of major importance to their forestry economies. In recent years, the establishment and management of planted teak forests have attracted large investments from the corporate sector in Latin America, Africa and Asia (FAO, 2010).

Irrigation of forest trees with wastewater for fuel and timber production is an approach which helps to overcome health hazards associated with sewage farming. Establishment of the green belts around the cities by forest trees under wastewater irrigation also helps revive the ecological balance and improves environmental conditions by self-treatment of wastewater through the application of forest irrigation. The use of sewage effluent in irrigating mahogany trees grown was an important agricultural

Corresponding Author: Bahnasy M. I., Forestry and Timber Tree Dept., Hort. Res. Institute, Agric. Res. Center, Egypt. E-mail: magdibahnasy@yahoo.com 
practice for improving soil properties, increasing fuel and timber production, with an economic cost and safe way to dispose wastewater (Hayssam et al., 2011).

The important technical consideration is whether clear, knot-free, and consequently high-grade timber is required. For example, wood of such quality is of little importance in plantations grown for: (i) firewood or fuel and domestic uses except poles, (ii) pulpwood and particle board, (iii) low grade saw timber for uses such as shuttering and packing cases (iv) protection such as shelterbelts, erosion control and dune stabilization - in fact, persistent lower branches are often an advantage. In contrast, clear, knot - free timber is highly desirable or essential for (i) veneer production for decorative use, match making and plywood to ease peeling, improve appearance and reduce blemishes, (ii) high- grade constructional timber where uniform strength and good machining, fishing and seasoning qualities are important, (iii) various type of poles, e.g. transmission, which need to be smooth for handling and free of surface snags or holes to prevent entry of fungi or termites into the heartwood which is often not penetrated by preservatives. It is emphasized however, that when the technical desirability of growing knot-free timber can only be achieved by pruning, it should be reflected in a higher price for the timber. Pruning should be viewed by the forester as an investment to improve wood quality which should command a higher market value, sufficient to cover the compounded pruning costs, compared with knotty timber from un-pruned trees (Evans, 1992).

International grading rules establish strict standards for classifying high-quality timber, which include the appearance of knots (number, frequency, diameter, sound or unsound). Yield and market prices considerably decrease for trees without pruning interventions, since lumber must be almost knotfree in order to obtain a high monetary value. Knots are widely considered as the most determinant defect for wood quality classification, in large part, because they influence the origin and magnitude of other defects such as pith eccentricity, stem form deviations (from the geometric cylinder shape), and bending (Rosso and Ninin, 1998).

Pruning is an important silviculture practice in commercial forest plantations because the trees tend to have multiple stems. Pruning is thus carried out to improve tree form and to increase tree strength, reduce stems or branch breakage, particularly after strong winds (Beadle et al., 2007).Furthermore, the capacity of Acacia mangium trees to self pruning is low in areas with high rainfall and pruning is consequently necessary (Lee and Arentz, 1997). These practices also reduce the density of stands so the optimum tree growth can be achieved (Neilsen and Gerrand, 1999). Pruning enhances overall growth rates and results in the production of knot- free stems (Alazard, 1996).

The main objective of teak plantation management is to produce high quality timber to meet the market demands. The term "quality" refers to the suitability of timber for particular end-uses which in the current context include sawn wood of desired dimensions for structural uses and veneer. The factors which dictate timber quality criteria of Teak plantations are: tree height and diameter, bole shape (taper, buttressing, fluting, etc.), branchiness (knot size and frequency), grain angle (degree and pattern of spiraility), juvenile and tension wood proportions, heartwood-sapwood ratio and heartwood characteristics (e.g. colour and extractives), proportion and arrangement of tissues including earlywood and latewood and cell dimensions. To enhance the productivity of Teak plantations the choice ofmanagement techniques envisaged include: genetic selection, wide planting spacement and /or thinning, pruning, fertilizer treatment, irrigation, etc. (Bhat and Indira, 1997). There are few recommendations regarding pruning intensities for forest plantations in Costa Rica. However, in general, it is recommended to prune tree up to $50 \%$ of the hight' total height just after the first thinning (Keogh, 1987 and Chaves and Fonseca, 1991). Pruning is primarily an economic decision and the extra effort for extensive pruning must be rewarded with a premium price (Víquez and Pérez, 2005). The important property requirements of fast-grown Tectona grandis L.F. plantations include straight bole with least taper, reduced flutes and buttresses, and knot-free volume. Unsound hollow knots and deep flutes are the two major factors influencing sawn wood grade. However, no adequate data are available for timber grown with intensive silvicultural practices including pruning (Bhat, 1998).

The goal of this study was to define the optimal pruning intensities on growth characteristics of some timber tree species i.e. Khaya senegalensis, Swietenia mahogani, Gmelinia arborea and Tectona grandis.

\section{Materials and Methods}

This experiment was carried out in Serapium forestry Plantation in North eastern Egypt ( $\mathrm{N} 30^{\circ}$ $28^{\prime \prime} 49.14^{\prime}$ E $\left.32^{\circ} 13^{\prime \prime} 29.86^{\prime}\right)$ within the Governorate of Ismailia, throughout three years $(2016,2017$ 
and 2018), with the aim to determine the optimal pruning intensities on growth characteristics (total height, root collar diameter, stem diameter at breast height(dbh), total biomass and total volume) of four tree species namely; Khaya senegalensis, Swietenia mahagoni, Gmelina arborea and Tectona grandis. These tree species are the most important tree species in Egypt and grows well under the Egypt climate conditions and wastewater irrigation.

\section{Experimental design:-}

One year old tree seedlings of Khaya senegalensis, Swietenia mahagoni, Gmelina arborea and Tectona grandis were transplanted in 2013 in Serapium plantation forest. The current study monitored the tree growth, above ground biomass and trees total volume of these species throughout three seasons (2016), (2017) and (2018), respectively. The tree species were distributed into three plots. Each plot was $12.5 \times 12.5 \mathrm{~m}$ contained 16 seedlings of each species with distance which planted at $2.5 \times 2.5 \mathrm{~m}$, uniform tree seedlings for all species were selected of height and stem diameter, ranged average (30$40 \mathrm{~cm}$ for height and $0.5-0.6 \mathrm{~cm}$ for stem diameter). The study was laid out in a complete randomized block design in split plot layout with three replicates; the irrigation with treated wastewater was a drip irrigation system.

\section{The pruning treatments:-}

Pruning was performed prior to the new growing season in February 2015 by removing all branches (live and dead) from outside the branch collar without damaging the main stem tissue, starting from ground level up to 30 and $50 \%$ of total tree height. So the pruning treatments were:-

1- control, non- pruning of branches

2-pruning intensity $30 \%$ of tree height

3 -pruning intensity $50 \%$ of tree height

Pruning was performed each year according to tree height. Total height was recorded as a reference to indicate the intensity of pruning.

\section{Growth measurements:-}

Annual total tree height $(\mathrm{m})$, root collar diameter $(\mathrm{cm})$ and annual increment in diameter at breast height $\mathrm{cm}(\mathrm{dbh})$ were taken as dependent variables to investigate the effects of pruning on trees as well as fresh and dry biomass $(\mathrm{kg} /$ tree), total volume $(\mathrm{m} /$ tree) and $\mathrm{N}, \mathrm{P}$ and $\mathrm{K} \%$ in the leaves of tree species. Nitrogen ( $\mathrm{N} \%$ ) was determined using the Kjeldahl method. Potassium (K \%) was determined by flame photometry, while Phosphorus (P \%) was determined by using colorimetric, determination according to the methods described by Pregl (1945); Piper (1950) and Brown and Lilliland (1946), respectively.

\section{Water analysis:-}

The chemical characteristics of used wastewater is shown in Table (1) as analyzed as methodology described in APHA, (1998).

Table 1: Chemical analysis of the treated wastewater used in irrigation of current study.

\begin{tabular}{|c|c|c|}
\hline No. & Parameter & Value \\
\hline 1 & TSS (mg/l) & 28.3 \\
\hline 2 & $\mathrm{pH}$ & 7.81 \\
\hline 3 & TDS (mg/l) & 640 \\
\hline 4 & BOD (mg/l) & 50.0 \\
\hline 5 & $\mathrm{NH}_{4}-\mathrm{N}(\mathrm{mg} / \mathrm{l})$ & 25.1 \\
\hline 6 & Total P (mg/l) & 2.49 \\
\hline 7 & $\mathrm{EC}\left(\mathrm{dsm}^{-1}\right)$ & 1.63 \\
\hline 8 & $\mathrm{~Pb}(\mathrm{mg} / \mathrm{l})$ & 0.007 \\
\hline 9 & $\mathrm{Ni}(\mathrm{mg} / \mathrm{l})$ & 0.019 \\
\hline 10 & $\mathrm{Cd}(\mathrm{mg} / \mathrm{l})$ & 0.001 \\
\hline 11 & $\mathrm{Cr}(\mathrm{mg} / \mathrm{l})$ & 0.024 \\
\hline 12 & $\mathrm{Zn}(\mathrm{mg} / \mathrm{l})$ & 0.064 \\
\hline 13 & $\mathrm{Fe}(\mathrm{mg} / \mathrm{l})$ & 0.374 \\
\hline 14 & $\mathrm{Cu}(\mathrm{mg} / \mathrm{l})$ & 0.019 \\
\hline
\end{tabular}




\section{Statistical analysis}

Data were statistically analyzed using the method described according to Snedecor and Cochran (1980). Using average L.S.D. values at $5 \%$ level.

\section{Results}

Effect of pruning intensity on total height (m) of some timber tree species after one, two and three years from pruning

The most common purpose of pruning is to produce knot- free wood called "clear wood". Also pruning has effect on the growth characteristics.

Data presented in Table (2) showed that, the total height of G. arborea was significantly increased $(6.31,7.38$ and $9.94 \mathrm{~m})$ at one, two and three years after pruning, respectively as compared to other tree species, followed with $S$. mahagoni (3.13, 4.02 and $4.87 \mathrm{~m}$ ), respectively as compared to the other tree species, with the exception of the differences between $S$. mahagoni and $K$. senegalensis which nonsignificant differed affected after three years from pruning only. Also the difference between $K$. senegalensis and $T$. grandis were non-significantly after one, two and three year from pruning.

Concerning the effect of pruning intensity on total height the same data cleared that $50 \%$ and $30 \%$ pruning intensity of tree height significantly increased total height $(4.14,4.91$ and $6.73 \mathrm{~m})$ and $(3.78,4.88$ and $6.42 \mathrm{~m})$ at one, two and three years after pruning respectively as compared to control .Also the difference between 30 and 50\% pruning intensity were non significantly after two and three years after pruning.

For the interaction between tree species and pruning treatments data presented in Table (2) illustrated that, G. arborea with $50 \%$ pruning intensity significantly increased total height $(7.83,8.23$ and $12.00 \mathrm{~m}$ ) at one, two and three years after pruning respectively as compared to other interactions, with the exception the difference between 30 and $50 \%$ pruning intensity of $G$. arborea was nonsignificant after two years after pruning only. Also the difference between $30 \%$ pruning intensity and control treatment was un-significantly.

Table 2: Effect of pruning intensity on total height (m) of some timber tree species after one, two and three years from pruning.

\begin{tabular}{|c|c|c|c|c|c|}
\hline $\begin{array}{l}\text { Tree species (A) } \\
\text { Pruning intensity (B) }\end{array}$ & $\begin{array}{c}K . \\
\text { senegalensis }\end{array}$ & $\begin{array}{c}S . \\
\text { mahagoni }\end{array}$ & $\begin{array}{c}G . \\
\text { arborea }\end{array}$ & $\begin{array}{c}T . \\
\text { grandis }\end{array}$ & Mean \\
\hline & \multicolumn{5}{|c|}{ (One year after pruning) 2016} \\
\hline Control (non- pruning) & 2.23 & 3.00 & 5.10 & 2.37 & 3.18 \\
\hline Pruning $30 \%$ of tree height & 2.90 & 3.00 & 6.00 & 3.23 & 3.78 \\
\hline Pruning $50 \%$ of tree height & 2.63 & 3.40 & 7.83 & 2.70 & 4.14 \\
\hline Mean & 2.59 & 3.13 & 6.31 & 2.77 & \\
\hline \multirow[t]{2}{*}{ LSD at 0.05} & \multicolumn{2}{|l|}{$\mathrm{A}=0.29$} & $\mathrm{~B}=0.34$ & \multicolumn{2}{|c|}{$\mathrm{AXB}=0.59$} \\
\hline & \multicolumn{5}{|c|}{ (Two years after pruning)2017 } \\
\hline Control (non- pruning) & 2.53 & 3.37 & 6.57 & 2.58 & 3.76 \\
\hline Pruning $30 \%$ of tree height & 4.07 & 3.83 & 7.35 & 4.27 & 4.88 \\
\hline Pruning $50 \%$ of tree height & 3.37 & 4.87 & 8.23 & 3.17 & 4.91 \\
\hline Mean & 3.32 & 4.02 & 7.38 & 3.34 & \\
\hline \multirow{2}{*}{ LSD at 0.05} & \multicolumn{2}{|l|}{$\mathrm{A}=0.60$} & $\mathrm{~B}=0.70$ & \multicolumn{2}{|c|}{$\mathrm{AXB}=1.21$} \\
\hline & \multicolumn{5}{|c|}{ (Three years after pruning)2018 } \\
\hline Control (non pruning) & 4.00 & 3.70 & 7.83 & 3.08 & 4.65 \\
\hline Pruning $30 \%$ of tree height & 5.33 & 4.67 & 10.00 & 5.67 & 6.42 \\
\hline Pruning $50 \%$ of tree height & 4.50 & 6.23 & 12.00 & 4.17 & 6.73 \\
\hline Mean & 4.61 & 4.87 & 9.94 & 4.31 & \\
\hline LSD at 0.05 & \multicolumn{2}{|l|}{$\mathrm{A}=0.49$} & $\mathrm{~B}=0.57$ & \multicolumn{2}{|c|}{$\mathrm{AXB}=0.98$} \\
\hline
\end{tabular}

Effect of pruning intensity on root collar diameter $(\mathrm{cm})$ of some timber tree species after one, two and three years from pruning.

Data presented in Table (3) revealed that the root collar diameter of $G$. arborea was significantly increased $(12.79,17.15$ and $18.88 \mathrm{~cm})$ at one, two and three years after pruning, respectively as compared to the other tree species. Followed with K.senegalensis and S.mahagoni where the difference 
between them were non-significantly at one, two and three years after pruning, also the difference between $K$. sengalensis, S. mahagoni and $T$. grands were non-significant after three years from pruning.

On the other hand, the same data cleared that pruning $30 \%$ and $50 \%$ of tree height significantly increased root collar diameter at one, two and three years after pruning as compared to non-pruning treatment, on the other hand $30 \%$ pruning intensity gave the highest value in root collar diameter $(10.04$, 12.83 and $14.86 \mathrm{~cm}$ ) at one, two and three years after pruning, respectively as compared to other treatments, with the exception of the difference between 30 and $50 \%$ pruning intensity were nonsignificantly at one and three years after pruning. However non- pruning treatment significantly decreased root collar diameter $(7.84,9.62$ and $11.44 \mathrm{~cm})$ at one, two and three years after pruning.

With regard to the interaction between tree species and pruning intensity treatments, data presented in Table(3) showed that $G$. arborea with 50 and $30 \%$ pruning intensity significantly increased root collar diameter $(14.03,18.53$ and $20.21 \mathrm{~cm})$ and $(12.70,18.00$ and $19.60 \mathrm{~cm})$ at one, two and three years after pruning respectively as compared with other interaction.

Table 3: Effect of pruning intensity on root collar diameter $(\mathrm{cm})$ of some timber tree species after one, two and three years from pruning.

\begin{tabular}{|c|c|c|c|c|c|}
\hline $\begin{array}{l}\text { Tree species (A) } \\
\text { Pruning intensity (B) }\end{array}$ & $\begin{array}{c}\text { K. } \\
\text { senegalensis }\end{array}$ & $\begin{array}{c}S . \\
\text { mahagoni }\end{array}$ & $\begin{array}{c}G . \\
\text { arborea } \\
\end{array}$ & $\begin{array}{l}T . \\
\text { grandis }\end{array}$ & Mean \\
\hline & \multicolumn{5}{|c|}{ (One year after pruning)2016 } \\
\hline Control (non- pruning) & 6.70 & 6.83 & 11.63 & 6.20 & 7.84 \\
\hline Pruning $30 \%$ of tree height & 9.67 & 9.27 & 12.70 & 8.53 & 10.04 \\
\hline Pruning $50 \%$ of tree height & 8.40 & 9.57 & 14.03 & 6.73 & 9.68 \\
\hline Mean & 8.26 & 8.56 & 12.79 & 7.16 & \\
\hline \multirow[t]{2}{*}{ LSD at 0.05} & \multicolumn{2}{|l|}{$\mathrm{A}=1.02$} & $\mathrm{~B}=1.18$ & \multicolumn{2}{|c|}{$\mathrm{AXB}=2.04$} \\
\hline & \multicolumn{5}{|c|}{ (Two years after pruning)2017 } \\
\hline Control (non- pruning) & 7.70 & 8.20 & 14.93 & 7.63 & 9.62 \\
\hline Pruning $30 \%$ of tree height & 12.13 & 10.97 & 18.00 & 10.20 & 12.83 \\
\hline Pruning $50 \%$ of tree height & 9.43 & 11.17 & 18.53 & 9.17 & 12.08 \\
\hline Mean & 9.75 & 10.11 & 17.15 & 9.00 & \\
\hline \multirow[t]{2}{*}{ LSD at 0.05} & \multicolumn{2}{|l|}{$\mathrm{A}=0.47$} & $\mathrm{~B}=0.54$ & \multicolumn{2}{|c|}{$\mathrm{AXB}=0.93$} \\
\hline & \multicolumn{5}{|c|}{ (Three years after pruning)2018 } \\
\hline Control (non- pruning) & 8.83 & 9.86 & 16.83 & 10.23 & 11.44 \\
\hline Pruning $30 \%$ of tree height & 14.00 & 12.57 & 19.60 & 13.26 & 14.86 \\
\hline Pruning $50 \%$ of tree height & 11.50 & 13.22 & 20.21 & 12.08 & 14.25 \\
\hline Mean & 11.44 & 11.88 & 18.88 & 11.86 & \\
\hline LSD at 0.05 & $\mathrm{~A}=1.22$ & & $\mathrm{~B}=1.41$ & \multicolumn{2}{|c|}{$\mathrm{AXB}=2.43$} \\
\hline
\end{tabular}

Effect of pruning intensity on diameter at breast height DBH (cm) of some timber tree species after one, two and three years from pruning.

Data in Table (4) cleared that, the diameter at breast height (dbh) of G. arborea significantly increased $(8.39,10.82$ and $11.69 \mathrm{~cm})$ at one, two and three years after pruning, respectively as compared to the other tree species. Followed with $S$. mahagoni $(3.64,5.61$ and $6.64 \mathrm{~cm})$, while the lowest value was at $T$. grandis and the difference between $T$. grandis and $K$. senegalensis were non-significantly after one, two and three years after pruning.

Concerning the effect of pruning intensity on diameter at breast height the same data showed that, pruning at 50 and $30 \%$ of tree height significantly increased dbh $(5.36,6.79$ and $7.99 \mathrm{~cm})$ and $(4.96$, 6.76 and $7.97 \mathrm{~cm}$ ) at one, two and three years after pruning respectively as compared to control (nonpruning) treatments but, the different between pruning intensity 30 and $50 \%$ were non- significantly.

As regards interaction between tree species and pruning treatments data presented in Table (4) indicated that, pruning at $50 \%$ of tree height significantly increased diameter at breast height of $G$. arborea $(10.33,12.20$ and $13.03 \mathrm{~cm})$ at one, two and three years after pruning, respectively as compared to other interactions. On other hand, control (non- pruning) treatment with all tree species significantly decreased diameter at breast height (dbh) with the exception of pruning intensity $50 \%$ with $T$. grandis at one year after pruning only. 
Table 4: Effect of pruning intensity on diameter at breast height DBH $(\mathrm{cm})$ of some timber tree species after one, two and three years from pruning.

\begin{tabular}{|c|c|c|c|c|c|}
\hline $\begin{array}{l}\text { Tree species (A) } \\
\text { Pruning intensity (B) }\end{array}$ & $\begin{array}{c}\text { K. } \\
\text { senegalensis }\end{array}$ & $\begin{array}{c}S . \\
\text { mahagoni }\end{array}$ & $\begin{array}{c}G . \\
\text { arborea }\end{array}$ & $\begin{array}{c}T . \\
\text { grandis }\end{array}$ & Mean \\
\hline & \multicolumn{5}{|c|}{ (One year after pruning)2016 } \\
\hline Control (non- pruning) & 2.34 & 2.80 & 6.80 & 2.40 & 3.59 \\
\hline Pruning $30 \%$ of tree height & 4.07 & 3.80 & 8.05 & 3.93 & 4.96 \\
\hline Pruning $50 \%$ of tree height & 3.97 & 4.33 & 10.33 & 2.82 & 5.36 \\
\hline Mean & 3.46 & 3.64 & 8.39 & 3.05 & \\
\hline \multirow[t]{2}{*}{ LSD at 0.05} & $\mathrm{~A}=0.44$ & & $\mathrm{~B}=0.51$ & & 0.88 \\
\hline & \multicolumn{5}{|c|}{ (Two years after pruning) 2017} \\
\hline Control (non- pruning) & 3.13 & 4.83 & 9.37 & 3.50 & 5.21 \\
\hline Pruning $30 \%$ of tree height & 5.03 & 5.80 & 10.90 & 5.30 & 6.76 \\
\hline Pruning $50 \%$ of tree height & 4.73 & 6.20 & 12.20 & 4.03 & 6.79 \\
\hline Mean & 4.30 & 5.61 & 10.82 & 4.28 & \\
\hline \multirow[t]{2}{*}{ LSD at 0.05} & \multicolumn{2}{|l|}{$\mathrm{A}=0.32$} & $\mathrm{~B}=0.37$ & \multicolumn{2}{|c|}{$\mathrm{AXB}=0.64$} \\
\hline & \multicolumn{5}{|c|}{ (Three years after pruning)2018 } \\
\hline Control (non- pruning) & 4.87 & 5.50 & 10.27 & 4.57 & 6.30 \\
\hline Pruning $30 \%$ of tree height & 6.77 & 7.00 & 11.77 & 6.33 & 7.97 \\
\hline Pruning $50 \%$ of tree height & 6.00 & 7.43 & 13.03 & 5.50 & 7.99 \\
\hline Mean & 5.88 & 6.64 & 11.69 & 5.47 & \\
\hline LSD at 0.05 & \multicolumn{2}{|l|}{$\mathrm{A}=0.52$} & $\mathrm{~B}=0.60$ & \multicolumn{2}{|c|}{$\mathrm{AXB}=1.03$} \\
\hline
\end{tabular}

Effect of pruning intensity on stem and branches fresh and dry weights $(\mathrm{kg})$ of some timber tree species after three years from pruning.

Data presented in Table (5) reveal that the stem fresh and dry weights of $G$. arborea significantly increased $(47.20$ and $17.76 \mathrm{~kg}$ ) at three years after pruning, respectively as compared to the other tree species, followed with $K$. sengalensis and T. grandis $(28.37,12.16$ and $21.12,8.55 \mathrm{~kg}) \mathrm{stem}$ fresh and dry weights, while $S$. mahagoni gave the lowest value of stem fresh and dry weight as compared to other tree species.

As for the effect of pruning intensity on stem fresh and dry weight the same data showed that pruning of $30 \%$ tree height significantly increased stem fresh and dry weights(35.29 and $14.57 \mathrm{~kg})$ followed with pruning $50 \%$ of tree height $(33.43$ and $14.16 \mathrm{~kg})$ at three years after pruning respectively as compared to control (non- pruning) treatment.

Concerning the interaction between tree species and pruning treatments data presented in Table (5) showed that, pruning intensity of 50\% tree height significantly increased stem fresh and dry weights for $G$. arborea $(72.00$ and $28.92 \mathrm{~kg}$ )respectively as compared to other interactions. However, control (non- pruning) with $T$. grandis significantly decreased stem fresh and dry weights $(9.29$ and $3.76 \mathrm{~kg}$ ) as compared to other interactions, with the exception of non- pruning treatment of $S$. mahagoni of only stem fresh and dry weights.

On the other side, branches fresh and dry weights data presented in Table (5) cleared that, branches fresh weight in $G$. arborea was significantly increased as compared to the other tree species $(18.50 \mathrm{~kg})$, while branches dry weight significantly increased in $G$. arborea, $S$. mahagoni and $K$. senegalensis with non- significant difference between themselves also the different between $K$. senegalensis and T. grandis was non- significant.

As for pruning intensity the same data showed that pruning intensity $30 \%$ of tree height significantly increased branches fresh and dry weights (18.30 and $7.26 \mathrm{~kg})$ as compared to other pruning intensity followed with intensity $50 \%$ of tree height $(14.05$ and $5.59 \mathrm{~kg})$ with the exception of the different between control treatment and intensity $50 \%$ of tree height was non- significantly in branches dry weight only.

Regarding the interaction between tree species and pruning intensity the same data cleared that pruning intensity $30 \%$ for K.senegalensis significantly increased branches fresh and dry weights $(25.00 \mathrm{and} 10.00 \mathrm{~kg})$, respectively as compared to other interactions. 
Table 5: Effect of pruning intensity on stemand branches fresh and dry weights $(\mathrm{kg})$ of some timber tree species after three years from pruning.

\begin{tabular}{|c|c|c|c|c|c|}
\hline $\begin{array}{l}\text { Tree species (A) } \\
\text { Pruning intensity (B) }\end{array}$ & $\begin{array}{c}\text { K. } \\
\text { senegalensis }\end{array}$ & $\begin{array}{c}S . \\
\text { mahagoni }\end{array}$ & $\begin{array}{c}G . \\
\text { arborea }\end{array}$ & $\begin{array}{c}T . \\
\text { grandis }\end{array}$ & Mean \\
\hline & \multicolumn{5}{|c|}{ Stem fresh weight } \\
\hline Control (non- pruning) & 12.30 & 10.60 & 31.70 & 9.29 & 15.97 \\
\hline Pruning $30 \%$ of tree height & 49.40 & 19.00 & 37.90 & 34.87 & 35.29 \\
\hline Pruning $50 \%$ of tree height & 23.40 & 19.13 & 72.00 & 19.20 & 33.43 \\
\hline Mean & 28.37 & 16.24 & 47.20 & 21.12 & \\
\hline \multirow[t]{2}{*}{ LSD at 0.05} & \multicolumn{2}{|l|}{$\mathrm{A}=1.48$} & $\mathrm{~B}=1.71$ & \multicolumn{2}{|c|}{$\mathrm{AXB}=2.97$} \\
\hline & \multicolumn{5}{|c|}{ Stem dry weight } \\
\hline Control (non- pruning) & 5.27 & 5.40 & 11.22 & 3.76 & 6.41 \\
\hline Pruning $30 \%$ of tree height & 21.17 & 9.85 & 13.14 & 14.11 & 14.57 \\
\hline Pruning $50 \%$ of tree height & 10.03 & 9.91 & 28.92 & 7.77 & 14.16 \\
\hline Mean & 12.16 & 8.39 & 17.76 & 8.55 & \\
\hline \multirow[t]{2}{*}{ LSD at 0.05} & \multicolumn{2}{|l|}{$\mathrm{A}=0.13$} & $\mathrm{~B}=0.15$ & \multicolumn{2}{|c|}{$\mathrm{AXB}=0.27$} \\
\hline & \multicolumn{5}{|c|}{ Branches with leaves fresh weight } \\
\hline Control (non- pruning) & 9.00 & 14.00 & 14.00 & 15.30 & 13.08 \\
\hline Pruning $30 \%$ of tree height & 25.00 & 13.20 & 21.50 & 13.50 & 18.30 \\
\hline Pruning $50 \%$ of tree height & 11.00 & 13.20 & 20.00 & 12.00 & 14.05 \\
\hline Mean & 15.00 & 13.47 & 18.50 & 13.60 & \\
\hline \multirow[t]{2}{*}{ LSD at 0.05} & \multicolumn{2}{|l|}{$\mathrm{A}=1.32$} & $\mathrm{~B}=1.52$ & \multicolumn{2}{|c|}{$\mathrm{AXB}=2.64$} \\
\hline & \multicolumn{5}{|c|}{ Branches with leaves dry weight } \\
\hline Control (non- pruning) & 3.60 & 7.00 & 4.60 & 6.00 & 5.30 \\
\hline Pruning $30 \%$ of tree height & 10.00 & 6.60 & 7.16 & 5.28 & 7.26 \\
\hline Pruning $50 \%$ of tree height & 4.40 & 6.60 & 6.66 & 4.70 & 5.59 \\
\hline Mean & 6.00 & 6.73 & 6.14 & 5.33 & \\
\hline LSD at 0.05 & \multicolumn{2}{|l|}{$\mathrm{A}=0.80$} & $\mathrm{~B}=0.92$ & \multicolumn{2}{|c|}{$\mathrm{AXB}=1.60$} \\
\hline
\end{tabular}

Effect of pruning intensity on total biomass fresh and dry weight (kg) of some timber tree species after three years from pruning.

Data presented in Table (6) cleared that, total biomass fresh and dry weights of G. arborea significantly increased $(65.70$ and $23.90 \mathrm{~kg})$ at three years after pruning, respectively as compared to the other tree species.

Table 6: Effect of pruning intensity on total biomass fresh and dry weight $(\mathrm{kg})$ of some timber tree species after three years from pruning.

\begin{tabular}{|c|c|c|c|c|c|}
\hline $\begin{array}{l}\text { Tree species(A) } \\
\text { Pruning intensity (B) }\end{array}$ & $\begin{array}{c}\text { K. } \\
\text { senegalensis }\end{array}$ & $\begin{array}{c}S . \\
\text { mahagoni }\end{array}$ & $\begin{array}{c}G . \\
\text { arborea }\end{array}$ & $\begin{array}{c}T . \\
\text { grandis }\end{array}$ & Mean \\
\hline & \multicolumn{5}{|c|}{ Total biomass fresh weight } \\
\hline Control (non- pruning) & 21.30 & 24.60 & 45.70 & 24.63 & 29.06 \\
\hline Pruning $30 \%$ of tree height & 74.40 & 32.20 & 59.40 & 48.37 & 53.59 \\
\hline Pruning $50 \%$ of tree height & 34.40 & 32.33 & 92.00 & 31.20 & 47.48 \\
\hline Mean & 43.37 & 29.71 & 65.70 & 34.73 & \\
\hline \multirow[t]{2}{*}{$\underline{\text { LSD at } 0.05}$} & \multicolumn{2}{|l|}{$\mathrm{A}=2.64$} & $\mathrm{~B}=3.04$ & \multicolumn{2}{|c|}{$\mathrm{AXB}=5.27$} \\
\hline & \multicolumn{5}{|c|}{ Total biomass dry weight } \\
\hline Control (non- pruning) & 8.87 & 12.40 & 15.82 & 9.76 & 11.71 \\
\hline Pruning $30 \%$ of tree height & 31.17 & 16.45 & 20.30 & 19.39 & 21.83 \\
\hline Pruning $50 \%$ of tree height & 14.43 & 16.51 & 35.58 & 12.47 & 19.75 \\
\hline Mean & 18.16 & 15.12 & 23.90 & \multirow{2}{*}{\multicolumn{2}{|c|}{$13.87 \mathrm{AXB}=0.87$}} \\
\hline LSD at 0.05 & $\mathrm{~A}=0.44$ & & $\mathrm{~B}=0.50$ & & \\
\hline
\end{tabular}

Regarding the effect of pruning intensity on total biomass fresh and dry weights the same data cleared that pruning intensity of $30 \%$ tree height significantly increased total biomass fresh and dry weights (53.59 and $21.83 \mathrm{~kg}$ ) at three years after pruning, respectively as compared to control (nonpruning) treatment.

Concerning the interaction between tree species and pruning treatments data presented in Table (6) showed that, pruning $50 \%$ of tree height significantly increased total biomass fresh and dry weights 
of $G$. arborea (92.00 and $35.58 \mathrm{~kg}$ ) at three years after pruning respectively as compared to any other interactions.

\section{Effect of pruning intensity on total volume $\left(\mathrm{m}^{3} /\right.$ tree) of some timber tree species after three years from pruning.}

Data presented in Table (7) showed that, pruning intensity of $50 \%$ increased total volume in $G$. arborea $0.066 \mathrm{~m}^{3} /$ tree followed by pruning intensity of $30 \%$ in $G$. arborea while the lowest value in total volume was in control( non- pruning) treatment $0.002 \mathrm{~m}^{3} /$ tree for $T$. grandis.

Table 7: Effect of pruning intensity on total volume $\left(\mathrm{m}^{3} /\right.$ tree) of some timber tree species after three years from pruning.

\begin{tabular}{|c|c|c|c|c|}
\hline Pruning intensity (B) & $\begin{array}{c}K . \\
\text { senegalensis }\end{array}$ & $\begin{array}{c}\text { S. } \\
\text { mahagoni }\end{array}$ & $\begin{array}{c}G . \\
\text { arborea }\end{array}$ & $\begin{array}{c}T . \\
\text { Grandis }\end{array}$ \\
\hline Control (non- pruning) & 0.008 & 0.011 & 0.024 & 0.002 \\
\hline Pruning $30 \%$ of tree height & 0.022 & 0.018 & 0.037 & 0.005 \\
\hline Pruning $50 \%$ of tree height & 0.010 & 0.026 & 0.066 & 0.003 \\
\hline
\end{tabular}

Effect of pruning intensity on $\mathrm{N}, \mathrm{P}$ and $\mathrm{K} \%$ in the leaves of some timber tree species after three years from pruning.

Data presented in Table (8) indicated tha, the highest N, P and K\% in the leaves of tree species was observed under pruning intensities. N, $\mathrm{P}$ and $\mathrm{K} \%$ were increased under $50 \%$ pruning intensity for G. arborea and S. mahagoni, while N, P and K values were increased under $30 \%$ pruning intensity in $K$. senegalensis and $T$. grandis

Table 8: Effect of pruning intensity on $\mathrm{N}, \mathrm{P}$ and $\mathrm{K} \%$ in the leaves of some timber tree species after three years from pruning.

\begin{tabular}{|c|c|c|c|c|c|c|c|c|c|c|c|c|}
\hline \multirow[t]{2}{*}{$\begin{array}{r}\text { Tree species (A) } \\
\text { Pruning intensity (B) }\end{array}$} & \multicolumn{3}{|c|}{$\begin{array}{c}K . \\
\text { senegalensis }\end{array}$} & \multicolumn{3}{|c|}{$\begin{array}{c}\text { S. } \\
\text { Mahagoni }\end{array}$} & \multicolumn{3}{|c|}{$\begin{array}{c}G . \\
\text { arborea }\end{array}$} & \multicolumn{3}{|c|}{$\begin{array}{c}T . \\
\text { Grandis }\end{array}$} \\
\hline & $\mathbf{N}$ & $\mathbf{P}$ & $\mathbf{K}$ & $\mathbf{N}$ & $\mathbf{P}$ & $\mathbf{K}$ & $\mathbf{N}$ & $\mathbf{P}$ & $\mathbf{K}$ & $\mathbf{N}$ & $\mathbf{P}$ & $\mathbf{K}$ \\
\hline Control (non- pruning) & 1.66 & 0.25 & 1.20 & 1.75 & 0.27 & 1.40 & 1.98 & 0.37 & 1.65 & 1.56 & 0.20 & 1.16 \\
\hline $\begin{array}{l}\text { Pruning } 30 \% \text { of tree } \\
\text { height }\end{array}$ & 2.24 & 0.35 & 1.84 & 1.86 & 0.32 & 1.65 & 2.51 & 0.42 & 1.85 & 1.97 & 0.34 & 1.66 \\
\hline $\begin{array}{l}\text { Pruning } 50 \% \text { of tree } \\
\text { height }\end{array}$ & 2.05 & 0.31 & 1.63 & 2.15 & 0.39 & 1.72 & 2.85 & 0.48 & 2.23 & 1.77 & 0.28 & 1.53 \\
\hline
\end{tabular}

\section{Discussion}

The most common reasons for pruning trees in plantations or woodlands are to maintain a single central leader, repair storm damage, or promote clear trunks or boles for eventual production of high grade lumber or veneer logs. These results have practical implications on growth of tree species under this study where pruning was used to improve stem form and growth. Pruning is the most common tree maintenance procedure. Because each cut has the potential to change the growth of the tree, no branch should be removed without a reason.

Common reasons for pruning are to remove dead branches, to remove crossing and rubbing branches, and to eliminate hazards. Trees may also be pruned to increase light and air penetration to the inside of the tree's crown or to the landscape below. In most cases, mature trees are pruned to prevent defects occurring or to correct those already present. Lower branches become shaded as the tree grows, these shaded branches do not produce sufficient carbohydrates. So the tree sheds these branches. They die and will eventually fell to the ground unless removed in advance through regular tree maintenance pruning.

Results, of this study showed clearly that pruning has a significant effect on the growth characteristics. The aforementioned results indicated that, pruning of $30 \%$ tree height significantly increased all growth characteristics (total height, root collar diameter, diameter at breast height and total biomass) in $K$. senegalensis and T. grandis. On the other hand pruning of $50 \%$ tree height significantly increased all growth characteristics studied in S. mahagoni and G. arborea. Also N, P and K in the tree species leaves were increased under 50\%pruning intensity of G. arborea and S. mahagoni, while N, P and $\mathrm{K}$ values were increased by $30 \%$ pruning intensity in $K$. senegalensis and $T$. grandis. 
These results are in accordance with Erkan et al., (2016) found that pruning is a technique used to add value to trees growing in forest stands, allowing the formation of clear, knote- free wood. Although many factors affect timber value, knots are the primary cause of reduction of conifers timber quality. Also it clear that pruning trees to improve timber quality can increase the economic value of woodlands. Formative pruning at an early age is beneficial for tree form and value. Also the results are harmony with Schneider et al., (1999) on Pinus elliottii they found that pruning intensities below $40 \%$ of total height are recommended. Also Alazard (1999) on pine (Pinus pinaster) showed that in good quality plantations, pruning enhance overall growth rates and results in the production of knot- free stems. (Pérez et al., 2003) found that at early stages (Five years of age), T. grandis trees can produce over 15 branches with a diameter up to $6.0 \mathrm{~cm}$ along the stem, reducing the wood quality severely if an adequate pruning regime is not implemented. Moreover, by that time the defect core diameter will be greater than $15 \mathrm{~cm}$, the pruning would be more expensive, and the economic feasibility of the activity may be threatened, as the percentage of knot-free volume that will be produced afterwards may be insufficient for obtaining high returns on the investment. Tarigen et al., (2011) Showed clearly that careful pruning could reduce the incidence of stem disease in Acacia plantations in Indonesia, will ensure the success of future plantings. Poor silvicultural practices, such as excessive pruning and rough pruning, should be actively avoided. Late pruning also results in large branches that are difficult to be pruned without significant damage to the stem and this practice should also be avoided Víquez and Pérez (2005) found that, the importance of implementing intensive pruning regimens, as inadequate interventions may threaten the growth, yield, and wood quality of $T$. grandis plantations. In addition, within the concept of an intensive management system, it is of a primary importance to develop a silvicultural strategy which includes both thinning and pruning and which clearly recognizes the relationship between these operations. Pruning up to $3.0 \mathrm{~m}$ high in the first intervention produces trees with high individual growth and heartwood formation, with a better dbh/total height relationship, and results in the most suitable pruning intensity option for reaching maximum stand total and heartwood volume. Majid and Paudyal (1992) consider that pruning should be done at early stages in order to restrict knotty cores to a minimum. Moreover, early pruning (at two or three years of age for tropical species) should be done on all trees to avoid suppression by neighboring trees. Also Gerrand et al., (1997) in Acacia mangium found that pruning should be executed early; when branches do not surpass $2.5 \mathrm{~cm}$ in diameter. International grading rules do not allow the presence of knots in "special" grade timber. For first quality or grade 1 , the permissible amount of knots are 1 per linear meter, with a maximum diameter of 1.25 $\mathrm{cm}$. For the lowest grade with international standards (grade 3), a total of 3knots per linear meter with a maximum of $3.81 \mathrm{~cm}$ of diameter is allowed. On teak tree the intensive pruning regime reduces number, frequency, and diameter of knots, the timber recovery and the grading may be improved considerably, as logs of higher quality will result in a higher timber recovery rate. Differences in total volume as product of the different pruning regimes were more evident in terms of heartwood volume than in terms of sapwood volume, showing the $3.0 \mathrm{~m}$ with the highest individual tree growth and heartwood content. Pruning of branches may have reduced the efficiency of sapwood in certain areas, enabling the formation of heartwood; all this without a detrimental effect on tree growth as the removed foliage represented less than 50\% of the total Pérez et al., (2003). Also Víquez and Pérez (2005) found that by means of an intensive pruning regime that reduces the number, frequency, and diameter of knots, the timber recovery and the grading may be improved considerably, as logs of higher quality will result in a higher timber recovery rate. Also these are results in accordance with Hevia et al., (2016) on Pinus radita and Pinus pinaster showed that pruning is a key silviculture intervention in order to obtain high quality wood products since it influences the size of the knotty core and the proportion of clear wood. Also they found the most severe pruning treatments had the greater influence on stem form, resulting in more cylindrical stems in both species. Also other studies showed that, Acacia species; however, tend to have poor stem form, with multiple stems and branches. Furthermore, the capacity of Acacia mangium trees to self prune is low in areas with high rainfall and pruning is necessary Lee and Arentz (1997). Pruning (singling) is thus carried out to improve tree form and to increase tree strength, reducing stem or branch breakage, particularly after strong winds Beadle et al., (2007).These practices also reduce the density of stands so that optimum tree growth can be achieved Neilsen and Gerrand (1999). 


\section{Conclusion}

Forest plantations in Egypt have expanded under using treated wastewater to provide wood for industry and other non wood forest products so; it is very important to set a strategy for the development of silviculture which includes both thinning and pruning.

According to this study, it can be concluded that, pruning is an important silviculture practice in commercial forest plantation because the trees tend to have multiple stems. Pruning is thus carried out to improve tree form and to increase tree strength, reduce stems or branches breakage, particularly after strong winds.

The aforementioned results indicated that all growth characteristics (total height, root collar diameter, diameter at breast height and total biomass) were significantly increased in G. arborea followed by S. mahagoni, K. senegalensis and T. grandis. Pruning of $30 \%$ tree height significantly increased all growth characteristics (total height, root collar diameter, diameter at breast height and total biomass) in $K$. senegalensis and $T$. grandis. On the other hand pruning of $50 \%$ tree height significantly increased all growth characteristics studied in S. mahagoni and G. arborea.

\section{References}

Alazard, P., 1996. The effect of pruning intensity on growth: branching characteristics of maritime pine. Informations-Forêt, Afocel-Armef, 3(532):6

APHA, 1998.American Public Health Association, Standard Methods for the Examination of Water and Wastewater. $20^{\text {th }}$ ed. Washington, DC.

Beadle C., K. Barry, E. Hardiyanto, R.J. Irianto, C. Mohammed and A. Rimbawanto, 2007. Effect of pruning Acacia mangium on growth, form and heart rot. Forest Ecology and Management, 238:261-267.

Bhat K.M. and E.P. Indira, 1997. Effect of faster growth on timber quality of Teak.KFRI.RES.REPT.132:1-68.

Bhat K.M., 1998. Properties of fast-grown teak wood: impact on end-user's requirements. Journal of Tropical Forest Products, 4(1): 1-10.

Brown, J.D. and O. Lilliland, 1946. Rapid determination of potassium and sodium in plant material and soil extracts by flame photometry. Proc. Amer. Soc. Hort. Sci., 48: 341-346.

Chaves, E. and W. Fonseca, 1991. Teca (Tectona grandis): especie de árbol de usomúltiple en América Central. Proyecto MADELEÑA (Cultivo de Árboles de UsoMúltiple en América Latina), colección Guías Silviculturales (serietécnica).Informetécnico 179.Centro Agronómico Tropical de Investigación y Enseñanza (CATIE), Turrialba, Costa Rica.44 .

Erkan, N., E. Uzun, A.C. Aydin and M.N. Bas, 2016. Effect of pruning on diameter Growth in Pinus brutiaTen. Plantations in Turkey. Croat. J. for Eng., 37(2):365-373.

Evans, J., 1992.Plantation Forestry in the Tropics. Second Edition. With Oxford University Press. P. 403.

FAO, 2010. Teak resources and market assessment, FAO Planted Forests and Trees Working Paper FP/47/E, Rome. http:/www.fao.org/forestry/plantedforests/67508@170537/en/

Gerrand, A.M., W.A. Neilsen and J.L. Medhurst, 1997. Thinning and pruning eucalypt plantations forSaw $\log$ production in Tasmania.Tas Forests, 9:15-34.

Hayssam M.A., M.E. Elsayd, F.A. Hassan and M.A. El-Tarawy, 2011. Usage of sewage effluent in irrigation of some woody tree seedlings. Part3. Swietenia mahagoni (L).Jacq. Saudi J. Biol Sci., 18(2):201-207.

HeviaA., J.G.A. Gonzalez and J. Majada, 2016. Effect of pruning on knotty core taper and form of Pinus radiate and Pinus pinaster. European J. of Wood and Wood Products, 74(5):751-752.

Keogh, R., 1987. The care and management of teak (Tectona grandis) plantations.A practical fieldguide for foresters in The Caribbean, Central America, Venezuela and Colombia. Universidad Nacional, Costa Rica, 46.

Lee S.S. and F. Arentz, 1997. A possible link between rainfall and heart rot incidence in Acacia mangium. Journal of Tropical Forest Science, 9: 441-448.

Majid N.M. and B.K. Paudyal, 1992. Pruning trial for Acacia mangium plantation in Peninsular Malaysia. Forest Ecology and Management, 47: 285-293. 
Neilsen W.A. and A.M. Gerrand, 1999. Growth and branching habit of Eucalyptus nitens at different spacings and the effect on final crop selection. Forest Ecology and Management, 123: 217-229.

Nikiema A. and D. Pasternak, 2008. Khaya senegalensis (Desr.) A. Juss. In: Louppe, D, OtengAmoako, AA, Brink, M. (eds.). Plant Resources of Tropical Africa. v. 7.PROTA Foundation, Wageningen, 339-344.

Orwa C., A. Mutua, R. Kindt, R. Jamnadass and S. Anthony, 2009. Agroforest tree Database: A tree reference and selection guide version 4.0 (http://www.worldagroforestry.org/sites/treedbs/ treedatabases.asp).

Perez D., E. Víquez and M. Kanninen, 2003. Preliminary pruning programme for Tectona grandis plantations in Costa Rica. Journal of Tropical Forest Science, 15(4): 557-569.

Piper, C.S., 1950. Soil and Plant Analysis. 1ST Ed.Inter science publishers Inc., New York, USA, 30229.

Pregl, F., 1945. Quantitive Organic Micro-analysis $4^{\text {th }}$. Edit., J. \&A. Churchill, Ltd., London.

Roshetko, J.M., J.M.R. Mulawarman, and P. Purnomosidhi, 2003. Gmelina arborea - a viable species for smallholder tree farming in Indonesia: Recent Advances with Gmelina arborea. New Forest, 28(2): 207-215.

Schneider, P.R., C.A.G. Finger, and J.M. Hoppe, (1999).The effect of pruning intensity on the production of Pinus elliottii Engelm., planted in a poor soil in the state of Rio Grande do Sul. Ciência Florestal, 9(1): 35-46.

Snedecor, G.W. and W.G. Cochran, 1980. Statistical Methods. $7^{\text {th }}$, the Iowa State Univ. Press. Ames., Iowa., U.S.A.,593.

Tarigan, M., M. J. Wingfield, M. van Wyk, B. Tjahjono and J. Roux, 2011. Pruning quality affects infection of Acacia mangium and A. crassicarpa by Ceratocysti sacaciivora and Lasiodiplodia theobromae, Southern Forests: a Journal of Forest Science, 73:3-4, 187-191.

Víquez, E. and D. Pérez, 2005. Effect of pruning on tree growth, yield, and wood properties of Tectona grandis plantations in Costa Rica. Silva Fennica, 39(3): 381-390. 